\title{
Upaya Meningkatkan Hasil Belajar Kimia Melalui Model Pembelajaran Student Teams Achievement Division (STAD) Bagi Siswa Kelas X
}

\author{
Yuni Tri Suparyatni \\ SMKN 1 Kapuas Murung, UPT. Dadahup A2, Desa Petak Batuah, \\ Kecamatan Dadahup, Kabupaten Kapuas, Kalimantan Tengah, Indonesia \\ younietris82@gmail.com
}

\begin{abstract}
Abstrak. Seiring berjalannya waktu dan perkembangan IPTEK, strategi pembelajaran juga terus mengalami perkembangan untuk mencapai pendidikan yang berkualitas. Pembelajaran yang cenderung kurang variatif dimana guru sebagai sumber utama pengetahuan lambat laun mulai dikembangkan dan mulai beralih pada model pembelajaran yang menuntut siswa turut aktif dalam kegiatan pembelajaran. Salah satu upaya guru untuk memperbaiki/meningkatkan aktivitas dan hasil belajar siswa dalam pembelajaran tentang Tatanama dan Rumus Kimia Senyawa adalah dengan menggunakan model pembelajaran kooperatif tipe STAD (Student Teams Avhievement Division) karena model pembelajaran ini sangat sederhana dan mudah dilakukan. Dari penelitian yang dilakukan didapatkan hasil bahwa pembelajaran kooperatif tipe Student Teams Achievement Division (STAD) dapat meningkatkan hasil belajar kimia siswa kelas X Jurusan ATPH SMKN 1 Kapuas Murung.
\end{abstract}

Kata Kunci: hasil belajar, kimia, model pembelajaran, STAD.

\section{PENDAHULUAN}

Seiring berjalannya waktu dan perkembangan IPTEK, strategi pembelajaran juga terus mengalami perkembangan untuk mencapai pendidikan yang berkualitas. Pembelajaran yang cenderung kurang variatif dimana guru sebagai sumber utama pengetahuan lambat laun mulai dikembangkan dan mulai beralih pada model pembelajaran yang menuntut siswa turut aktif dalam kegiatan pembelajaran. Penggunaan model pembelajaran yang tepat merupakan suatu alternatif mengatasi masalah rendahnya daya serap siswa terhadap mata pelajaran kimia. Penerapan suatu model pembelajaran juga harus ditinjau dari segi keefektifan, keefisienan, dan kecocokan dengan karakteristik materi pelajaran serta keadaan siswa (Mulyasa, 2008:8).

Proses pembelajaran kimia akan lebih baik apabila siswa berperan aktif yaitu siswa ditempatkan sebagai subyek pembelajaran dan guru sebagai pengelola proses pembelajaran. Keberhasilan pembelajaran kimia dapat diukur dari keberhasilan siswa dalam mengikuti kegiatan pembelajaran. Keberhasilan itu dapat dilihat dari pemahaman siswa, penguasaan materi serta prestasi siswa.

Berdasarkan pengamatan selama pembelajaran materi "Tatanama dan Rumus kimia Senyawa" kemampuan siswa kelas X Jurusan ATPH menunjukkan kemampuan yang rendah. Dari 24 siswa, ditemukan hanya 8 orang (33\%) yang berhasil mencapai KKM 65. Sisanya sejumlah 16 siswa atau sebesar $67 \%$ tidak berhasil mencapai KKM yang telah ditetapkan guru, yaitu di bawah KKM 65. Artinya siswa kelas X Jurusan ATPH mengalami masalah/kesulitan dalam memahami "Tatanama dan Rumus kimia Senyawa". Rendahnya kemampuan siswa pada "Tatanama dan Rumus kimia Senyawa" tersebut ditandai dengan hal-hal berikut:

- Siswa tidak fokus saat pembelajaran berlangsung,

- Siswa tidak aktif, dan sebagian besar hanya diam mendengar penjelasan guru,

- Siswa tidak banyak yang mengajukan pertanyaan, 
- Siswa tidak berani menjawab pertanyaan,

- Jawaban siswa masih jauh dari konsep yang tepat.

Selama ini, guru hanya menyajikan pembelajaran tentang Tatanama dan Rumus kimia Senyawa hanya dengan menggunakan ceramah dan metode penugasan tanpa refleksi sehingga siswa tidak aktif dan tidak mendapat pengalaman belajar yang bermakna sesuai dengan konteks dan pengalamannya sehari-hari. Oleh karena itu, kemampuan dan aktivitas siswa perlu ditingkatkan.

Salah satu upaya guru untuk memperbaiki/meningkatkan aktivitas dan hasil belajar siswa dalam pembelajaran tentang Tatanama dan Rumus kimia Senyawa adalah dengan menggunakan model pembelajaran kooperatif tipe STAD (Student Teams Achievement Division) karena model pembelajaran ini sangat sederhana dan mudah dilakukan.

Pada model pembelajaran ini para siswa dibagi dalam tim belajar yang terdiri atas empat orang yang berbeda-beda tingkat kemampuan, jenis kelamin, dan latar belakang etniknya. Guru menyampaikan pelajaran, lalu siswa bekerja dalam tim mereka untuk memastikan bahwa semua anggota tim telah menguasai pelajaran. Selanjutnya semua siswa mengerjakan kuis mengenai materi secara sendiri-sendiri, dimana saat itu mereka tidak diperbolehkan untuk saling bantu (Slavin, 2010: 11).

Dalam penelitian tindakan kelas ini, peneliti merumuskan masalah dalam bentuk pertanyaan sebagai berikut:

a. Apakah penggunaan model pembelajaran STAD dapat meningkatkan hasil belajar siswa kelas X Jurusan ATPH SMKN 1 Kapuas Murung tahun pelajaran 2015/2016?

b. apakah dengan model pembelajaran kooperatif tipe STAD dapat meningkatkan aktivitas siswa kelas X Jurusan ATPH SMKN 1 Kapuas Murung tahun pelajaran 2015/2016?

Adapun tujuan dari penelitian ini adalah sebagai berikut:

(1) untuk mengetahui peningkatan hasil belajar kimia siswa kelas X Jurusan ATPH SMKN 1 Kapuas Murung menggunakan model pembelajaran kooperatif tipe STAD,

(2) untuk mengetahui peningkatan ativitas siswa kelas X SMKN 1 Kapuas Murung menggunakan model pembelajaran kooperatif tipe STAD.

Hasil penelitian ini diharapkan dapat bermanfaat, diantaranya bagi:

a. Guru

1. Meningkatkan efektifitas kegiatan pembelajaran melalui model pembelajaran kooperatif tipe STAD.

2. Sebagai bahan referensi untuk memperbaiki kegiatan pembelajaran di kelas.

3. Sebagai bahan pertimbangan bagi guru untuk menerapkan pembelajaran kooperatif tipe STAD pada pokok bahasan yang lain.

b. Siswa

1. Menumbuhkan motivasi belajar siswa.

2. Mengatasi kejenuhan siswa dalam kegiatan pembelajaran.

3. Melatih siswa berkolaborasi dengan siswa lain.

c. Sekolah

Dapat digunakan sebagai bahan masukan bagi perbaikan kualitas pembelajaran di kelas.

\section{METODE PENELITIAN}

Penelitian ini dirancang dan dilaksanakan dengan menggunakan penelitian tindakan kelas (PTK). Penelitian tindakan kelas (PTK) adalah penelitian tindakan (action research) yang dilakukan di kelas dengan tujuan memperbaiki atau meningkatkan mutu praktik pembelajaran (Suhardjono, 2008). 
Menurut Iskandar (2009) secara umum penelitian tindakan kelas (PTK) dilaksanakan dalam bentuk siklus berulang-ulang, empat bagian utama yang ada dalam setiap siklus adalah sebagai berikut :

(1) perencanaan (planning),

(2) pelaksanaan (acting),

(3) pengamatan (observing), dan

(4) refleksi (reflecting).

Subjek dalam penelitian ini adalah siswa kelas X Jurusan ATPH SMK Negeri 1 Kapuas Murung tahun pelajaran 2015/2016 sebanyak 24 orang yang terdiri dari 17 orang siswa laki-laki dan 7 orang siswa perempuan. Objek penelitian adalah hasil belajar kimia siswa kelas X Jurusan ATPH SMK Negeri 1 Kapuas Murung tahun pelajaran 2015/2016 pada pokok bahasan Tatanama dan Rumus Kimia Senyawa.

Penelitian dilaksanakan pada semester ganjil tahun pelajaran 2015/2016 di kelas X Jurusan ATPH SMK Negeri 1 Kapuas Murung yang beralamat di desa Petak Batuah (A2) Kecamatan Dadahup Kabupaten Kapuas Provinsi Kalimantan Tengah. Penelitian berlangsung mulai tanggal 15 Oktober 2015 s.d. 19 November 2015 sebanyak 2 siklus dengan jumlah keseluruhan pertemuan 6 kali, dimana 2 kali pertemuan dialokasikan untuk proses pembelajaran dan 1 kali pertemuan untuk evaluasi akhir.

Teknik yang digunakan untuk mengumpulkan data dalam penelitian tindakan kelas ini terdiri dari: Dokumentasi ini berupa nilai ulangan harian mata pelajaran kimia siswa pada kelas X Jurusan ATPH. Kemudian data tersebut digunakan sebagai dasar untuk membentuk kelompok siswa yang heterogen berdasarkan kemampuan akademik. Instrumen ini dilakukan dengan memberikan instrumen tes kepada siswa yaitu berupa evaluasi di setiap akhir siklus. Dalam penelitian ini soal yang digunakan berbentuk essay sebanyak 5 soal. Lembar observasi digunakan untuk memperoleh data mengenai aktivitas siswa selama proses pembelajaran dengan menggunakan model pembelajaran kooperatif tipe $S T A D$ dan dilaksanakan oleh pengamat atau observer.

Teknik yang digunakan untuk menganalisis data dalam penelitian ini adalah: Data hasil belajar siswa dianalisis menggunakan teknik statistik deskriptif, yaitu untuk melihat peningkatan nilai rata-rata hasil belajar siswa. Untuk menghitung nilai rata-rata hasil belajar siswa menggunakan rumus dari Sudjana (2008), yaitu:

$$
\begin{aligned}
& \qquad \overline{\mathrm{X}}=\frac{\sum \mathrm{X}}{\mathrm{N}} \\
& \text { Keterangan : } \\
& \overline{\mathrm{X}}=\text { rata-rata (mean) } \\
& \sum \mathrm{X}=\text { jumlah seluruh skor } \\
& \mathrm{N} \quad=\text { banyaknya subjek }
\end{aligned}
$$

Teknik yang digunakan untuk menganalisis data hasil observasi aktivitas siswa yaitu teknik statistik deskriptif menggunakan modus. Cara penilaian hasil belajar siswa secara individu ditentukan dengan menggunakan rumus dari Usman dan Setiawati (2001), yaitu :

$$
\text { Nilai akhir }=\frac{\text { Skor perolehan }}{\text { Skor maksimal }} \times 100
$$

Persentase data hasil belajar dan respon siswa dihitung dengan menggunakan rumus dari Sudijono (2008) adalah sebagai berikut :

Keterangan:

$$
P=\frac{f}{N} \times 100 \%
$$

$P=$ angka persentase

$f=$ frekuensi yang sedang dicari persentasenya

$N=$ jumlah frekuensi/banyaknya individu 
Hasil belajar siswa setiap akhir siklus yang dinyatakan dalam bentuk persentase menyatakan ketuntasan belajar secara klasikal.

\section{HASIL PENELITIAN DAN PEMBAHASAN}

Berdasarkan hasil pengamatan dan penilaian terhadap aktivitas siswa diperoleh data bahwa tidak semua siswa antusias mengikuti pelajaran terutama pada aspek aktif dalam mengerjakan tugas. Hanya siswa yang tergolong pintar saja yang aktif mengerjakan tugas, hal ini menunjukkan bahwa kegiatan berkelompok siswa belum sepenuhnya berhasil.. Tanggapan dari siswa yang lain pun hampir tidak ada. Untuk pengelolaan pembelajaran yang dilakukan oleh guru secara keseluruhan telah berlangsung dengan cukup lancar, hanya saja pada aspek pengelolaan waktu pengamat menilai bahwa guru masih belum sepenuhnya berhasil melaksanakannya. Selain itu, menurut pengamat pada aspek pemberian motivasi belajar kepada siswa juga dirasakan masih kurang dan perhatian yang diberikan guru kepada setiap kelompok tampaknya belum begitu merata sehingga ada beberapa kelompok merasa tidak diperhatikan dan akibatnya terjadi keributan. Setelah dilakukan perhitungan oleh peneliti, secara keseluruhan aktivitas siswa di kelas selama pembelajaran kimia berlangsung termasuk dalam kualifikasi cukup baik.

Daftar nilai evaluasi siklus I lebih lengkap dapat dilihat pada tabel berikut:

Tabel 1 Persentase kualifikasi hasil belajar siswa pada siklus I

\begin{tabular}{|l|l|c|c|}
\hline Nilai & Kualifikasi & Frekuensi & Persentase (\%) \\
\hline$\geq 95$ & Istimewa & 2 & 8,33 \\
$80,0-94,9$ & Amat baik & 4 & 16,67 \\
$65,0-79,9$ & Baik & 9 & 37,50 \\
$55,0-64,9$ & Cukup & 3 & 12,50 \\
$40,1-54,9$ & Kurang & 5 & 20,83 \\
$\leq 40,0$ & Amat kurang & 1 & 4,17 \\
\hline Jumlah & & 24 & 100,00 \\
\hline
\end{tabular}

Berdasarkan hasil evaluasi siklus I terlihat bahwa hasil belajar siswa pada siklus I belum memenuhi indikator keberhasilan penelitian yang telah ditetapkan. Ketuntasan belajar siswa secara klasikal hanya sebanyak $62,50 \%$ atau 15 orang siswa dari keseluruhan jumlah siswa dengan nilai rata-rata siswa adalah 72,26 maka dapat dinyatakan bahwa pembelajaran siklus I belum berhasil secara optimal karena siswa yang memperoleh nilai $\geq 65$ belum mencapai $75 \%$ dari jumlah siswa keseluruhan.

Skor perkembangan untuk masing-masing kelompok dalam siklus I dapat dilihat pada tabel berikut ini.

Tabel 2 Skor perkembangan kelompok pada siklus I

\begin{tabular}{|c|c|c|c|c|c|c|}
\hline Nama Kelompok & A & B & C & D & E & F \\
\hline Nilai & 28,33 & 25,00 & 20,00 & 18,00 & 22,00 & 24,00 \\
\hline Penghargaan & Super & super & Hebat & baik & hebat & hebat \\
\hline
\end{tabular}

Terlihat dari skor perkembangan kelompok, ada satu kelompok yang rata-rata skornya masih dibawah 20. Hal ini dikarenakan siswa masih kurang bekerja sama dalam kelompok, hanya siswa yang pintar yang lebih aktif. Berdasarkan skor perkembangan kelompok, ada satu kelompok siswa yang memiliki skor kelompok tertinggi sehingga memperoleh predikat kelompok super dan mendapatkan penghargaan. Kelompok ini diberikan hadiah dengan harapan dapat menambah motivasi kelompok mereka dan kelompok lain dalam belajar.

Berdasarkan hasil observasi dan evaluasi selama pelaksanaan siklus I, ada beberapa hal penting yang perlu diperhatikan dan diperbaiki untuk perencanaan tindakan pada 
siklus selanjutnya. Kegiatan pembelajaran dengan menggunakan model pembelajaran kooperatif tipe STAD pada siklus I belum sepenuhnya berjalan dengan cukup baik. Terlihat siswa belum terbiasa dengan pembelajaran kooperatif sehingga kebanyakan dari mereka tidak begitu aktif dalam bekerja kelompok terutama dalam mengerjakan lembar kerja kelompok yang diberikan. Mungkin hal ini disebabkan kurangnya motivasi dan bimbingan guru kepada siswa. Kemudian dalam hal pengelolaan waktu pembelajaran yang dilakukan oleh guru dirasa belum begitu efektif. Selain itu juga, perhatian yang diberikan guru kepada setiap kelompok tampaknya belum begitu merata sehingga ada beberapa kelompok merasa tidak diperhatikan dan akibatnya terjadi keributan.

Siklus II dilaksanakan 3 kali pertemuan yaitu pada tanggal 5, 12 dan 19 November 2015. Siswa disajikan materi tentang tatanama senyawa asam, basa dan organik dengan menerapkan model pembelajaran kooperatif tipe STAD pada pertemuan pertama. Siswa disajikan materi tentang tentang rumus kimia senyawa dengan menerapkan model pembelajaran kooperatif tipe STAD pada pertemuan kedua. Pada pertemuan ketiga dilakukan evaluasi akhir siklus II. Guru kembali melakukan kegiatan pembelajaran dengan menggunakan model pembelajaran kooperatif tipe STAD sesuai dengan RPP siklus II yang telah dibuat. Hasil observasi yang teramati pada siklus II berjalan dengan baik. Pada siklus ini waktu yang digunakan dapat diatur dengan baik, tidak terlihat lagi rasa canggung antar anggota kelompok, setiap anggota kelompok saling membantu agar kelompoknya memperoleh nilai tertinggi. Interaksi antara siswa dengan guru juga meningkat, siswa sudah mulai terbiasa untuk bertanya jika mereka merasa kesulitan dalam memahami materi yang diajarkan. Mereka juga sudah berani untuk memberikan ide atau tanggapan terhadap guru. Siswa sudah dapat membuat kesimpulan sendiri dari pembelajaran serta dapat berinteraksi dengan baik terhadap siswa lain di luar kelompok. Perhatian guru kepada semua kelompok siswa merata sehingga semua kelompok bersemangat dalam kegiatan berkelompok. Setelah dilakukan perhitungan oleh peneliti, secara keseluruhan aktivitas siswa di kelas selama pembelajaran kimia berlangsung termasuk dalam kualifikasi baik.

Daftar nilai evaluasi siklus II disajikan pada tabel berikut.

Tabel 3 Persentase kualifikasi hasil belajar siswa pada siklus II

\begin{tabular}{|l|l|c|c|}
\hline Nilai & Kualifikasi & Frekuensi & Persentase (\%) \\
\hline$\geq 95$ & Istimewa & 5 & 20,83 \\
$80,0-94,9$ & Amat baik & 6 & 25,00 \\
$65,0-79,9$ & Baik & 8 & 33,33 \\
$55,0-64,9$ & Cukup & 3 & 12,50 \\
$40,1-54,9$ & Kurang & 2 & 8,33 \\
$\leq 40,0$ & Amat kurang & 0 & 0 \\
\hline Jumlah & 24 & 100,00 \\
\hline
\end{tabular}

Terlihat bahwa sudah $79,17 \%$ siswa telah memenuhi kriteria keberhasilan. Sebaliknya hanya $20,83 \%$ siswa yang belum memenuhi kriteria keberhasilan. Dengan mengacu pada kriteria tindakan yang telah ditetapkan maka dapat dinyatakan bahwa pembelajaran siklus II dapat dikatakan tuntas karena siswa yang memperoleh nilai $\geq 65$ sudah mencapai $75 \%$ dari jumlah siswa keseluruhan.

Perolehan skor perkembangan kelompok pada siklus II dapat dilihat pada tabel berikut: 
Tabel 4 Skor perkembangan kelompok pada siklus II

\begin{tabular}{|c|c|c|c|c|c|c|}
\hline Nama Kelompok & A & B & C & D & E & F \\
\hline Nilai & 21,67 & 20,00 & 26,67 & 22,00 & 28,00 & 24,00 \\
\hline Penghargaan & hebat & hebat & super & hebat & super & hebat \\
\hline
\end{tabular}

Terlihat dari skor perkembangan kelompok, semua kelompok mempunyai skor ratarata perkembangan yang lebih dari 15 .

Pengamatan dan penilaian terhadap aktivitas siswa yang dilakukan oleh pengamat diperoleh data bahwa semua siswa antusias mengikuti pelajaran, semua aspek aktivitas siswa dalam pembelajaran kooperatif sudah terpenuhi dan termasuk dalam kualifikasi baik. Selain terjadi peningkatan dalam aktivitas siswa, hasil belajar siswa juga meningkat. Peningkatan ketuntasan belajar secara klasikal sebesar 16,67\% dan 10,53 untuk nilai rata-rata hasil belajar siswa. Guru bisa dikatakan sudah mampu melaksanakan semua rencana tindakan yang telah dibuat. Karena ketuntasan belajar siswa sudah memenuhi indikator keberhasilan penelitian maka pengajar, pengamat dan peneliti sepakat untuk menghentikan penelitian dan tidak melanjutkan ke siklus berikutnya.

\section{KESIMPULAN}

Berdasarkan hasil dari penelitian maka diperoleh beberapa kesimpulan sebagai berikut:

1. pembelajaran kooperatif tipe Student Teams Achievement Division (STAD) dapat meningkatkan hasil belajar kimia siswa kelas X Jurusan ATPH SMKN 1 Kapuas Murung tahun pelajaran 2015/2016,

2. pembelajaran kooperatif tipe Student Teams Achievement Division (STAD) dapat meningkatkan aktivitas siswa kelas X Jurusan ATPH SMKN 1 Kapuas Murung tahun pelajaran 2015/2016.

Saran-saran yang dapat dikemukakan berkenaan dengan hasil penelitian ini adalah sebagai berikut:

(1) guru bidang studi kimia hendaknya menerapkan model pembelajaran kooperatif tipe STAD, karena model pembelajaran ini adalah salah satu alternatif dalam meningkatkan hasil belajar kimia siswa,

(2) mengingat berbagai keterbatasan yang ada dalam penelitian ini, kiranya perlu dilakukan penelitian sejenis dengan tempat dan karakteristik yang berbeda.

\section{DAFTAR RUJUKAN}

Djamarah, S.B. 2002. Psikologi Belajar. Rineka Cipta, Jakarta.

Djamarah, S.B. \& A. Zain. 2006. Strategi Belajar Mengajar. Rineka Cipta, Jakarta.

Ibrahim, M., F. Rachamadiarti, M. Nur \& Ismono. 2000. Pembelajaran Kooperatif. University Press, Surabaya.

Iskandar. 2009. Penelitian Tindakan Kelas. Gaung Persada Press, Jambi.

Mulyasa, E. (2007). Kurikulum Tingkat Satuan Pendidikan Suatu Panduan Praktis.

Bandung: Remaja Rosda Karya

Mundilarto, R. 2004. Penelitian Tindakan Kelas. Departemen Pendidikan Nasional, Jakarta.

Slavin, Robert E. (2010). Cooperative Learning Teori Riset Dan Praktik. Bandung: Nusa Media.

Sudjana, N. 2008. Penilaian Hasil Proses Belajar Mengajar. PT. Remaja Rosdakarya, Bandung.

Warsita, Bambang (2008). Teknologi Pembelajaran Landasan Dan Aplikasinya. Jakarta: Rineka Cipta. 